\title{
Unique minimally invasive management of cervicovaginal agenesis
}

\author{
Kavita Khoiwal (1) , Anchal Agarwal, Anoosha K Ravi, Jaya Chaturvedi
}

Department of Obstetrics \& Gynaecology, All India Institute of Medical Sciences, Rishikesh, India

\section{Correspondence to Dr Kavita Khoiwal; kavita.kh27@gmail.com}

Accepted 13 April 2021

\section{DESCRIPTION}

A 10-year-old premenarchal girl presented with worsening abdominal pain for 3 months. She had undergone laparotomy twice at 1 and 9 years of age for urogenital sinus and subacute intestinal obstruction, respectively. Abdominal examination revealed two healed, puckered scars (midline vertical infraumbilical and transverse suprapubic) and a suprapubic bulge corresponding to 14 weeks of uterus. Local examination showed a blind vaginal pouch (figure 1A). No cervical tissue was felt on rectal examination. Ultrasound (USG) pelvis suggested collection in endometrial cavity, that is haematometra (figure 1B). A provisional diagnosis of cervicovaginal agenesis (U0C4V4) was made. These findings were confirmed by MRI. In view of high possibility of intra-abdominal adhesions owing to previous two laparotomies, USG-guided transvaginal cervicovaginoplasty was planned.

First, McIndoe vaginoplasty was performed by dissecting in between the bladder and the rectum. A bluish bulge was seen at the apex of the neovagina. Under USG guidance, a long artery forceps was introduced through the vaginal bulge and pushed into the endometrial cavity (figure 1C,D). Soon after that, approximately $200 \mathrm{cc}$ of chocolatecoloured fluid was drained out (figure 2A). To keep the neocervix patent, a silicone malecot's catheter 16 French was inserted in the uterine cavity

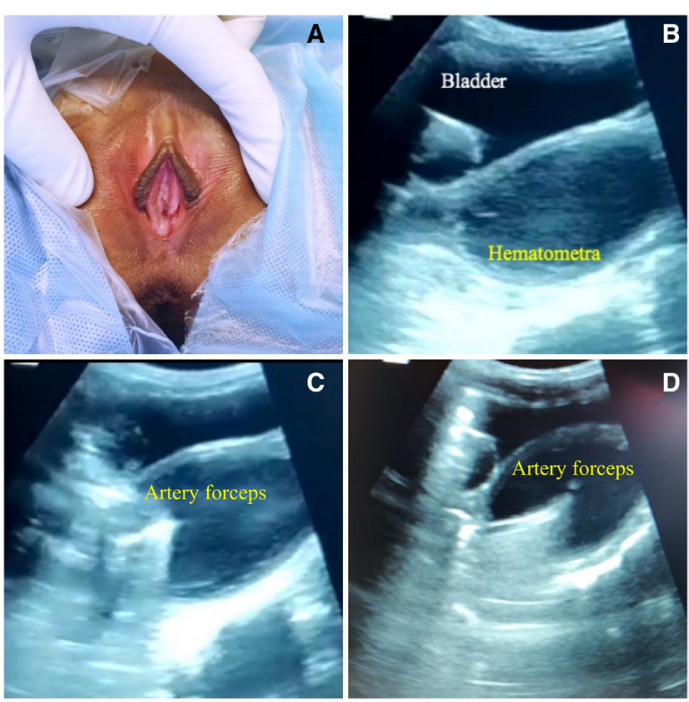

Figure 1 (A) Image shows blind vagina. (B) Ultrasound image suggestive of collection in the endometrial cavity (haematometra). (C, D) Images depict the introduction of a long artery forceps into the endometrial cavity under ultrasound guidance.

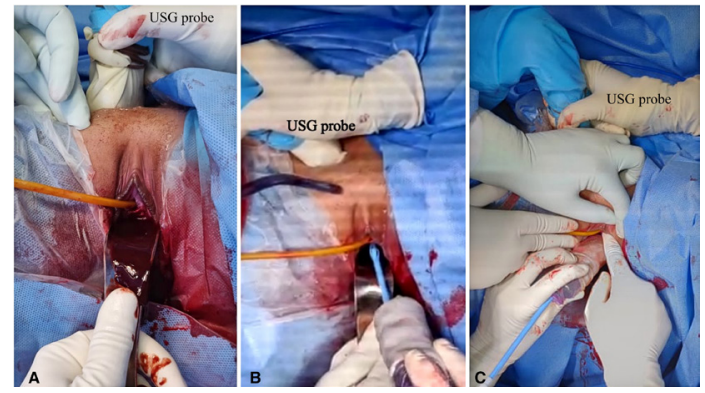

Figure 2 (A) Illustrates drainage of chocolate-coloured fluid from the endometrial cavity. (B, C) A silicone malecot's catheter encircled by foam mould being inserted in the uterine cavity. USG, ultrasound.

through the neocervix, and the foam mould encircling the malecot catheter was kept in the neovagina (figure $2 \mathrm{~B}, \mathrm{C}$ ) to avoid reapproximation of the vaginal walls. There were no intraoperative and postoperative complications. The foam mould was replaced by a glass mould on the seventh postoperative day while the malecot catheter was kept in situ. The patient is having normal menses for the last 9 months.

The occurrence of cervical agenesis is quite uncommon (1:80 000-1:100 000) and only 39\% of these cases simultaneously have vaginal agenesis. ${ }^{12}$ Initially, these cases were managed by hysterectomy or abdominal cervicovaginoplasty. ${ }^{3-5}$ Later, a minimally invasive approach came to light with the advent of laparoscopy and surgical expertise..$^{6-9}$

The aim of conservative management (open/laparoscopic) is to preserve the uterus by creating a path from the endometrial cavity to the vagina for the

\section{Patient's perspective}

Our young daughter was suffering from abdominal pain every month for 3 months in the last year. She was found to have some congenital anomaly in which the birth canal was not formed by birth. We were worried as our little daughter has already undergone two abdominal surgeries and doctors outside explained a high chance of injury to intestine. Then we came to this hospital. Here the doctor performed the procedure with the help of ultrasound. We were happy after the procedure as she was relieved of her monthly abdominal pain, and she is now having regular menstrual cycles. She is using vaginal mould on her own and we regularly visit gynaecology outpatient department for follow-up. 


\section{Learning points}

Cervical agenesis is a rare entity and less than $40 \%$ of cases are associated with vaginal agenesis.

- Cervicovaginal agenesis is routinely managed by hysterectomy or abdominal cervicovaginoplasty.

- Ultrasound-guided creation of neocervix without entering the abdomen is a challenging procedure and must be performed with caution, by gynaecologists trained in ultrasound-guided procedures.

passage of menstrual blood. In our case, we performed a similar procedure vaginally under USG guidance. The procedure was technically difficult as the abdomen was not entered. However, such a technique carries a high risk of bladder and rectal injury. Hence, it should be performed with caution and only performed by gynaecologists expert in USG-guided procedures.

Contributors KK, AA and AKR managed the case under the guidance of JC. KK had the idea of the study. AA and AKR prepared the manuscript. KK and JC critically revised the manuscript. All authors accepted the final version of the manuscript.

Funding The authors have not declared a specific grant for this research from any funding agency in the public, commercial or not-for-profit sectors.

Competing interests None declared.

Patient consent for publication Parental/guardian consent obtained.
Ethics approval Approved from Institutional Ethical Committee (AlIMS/IEC/21/67)

Provenance and peer review Not commissioned; externally peer-reviewed.

\section{ORCID iD}

Kavita Khoiwal http://orcid.org/0000-0002-3156-7486

\section{REFERENCES}

1 Suganuma N, Furuhashi M, Moriwaki T, et al. Management of missed abortion in a patient with congenital cervical atresia. Fertil Steril 2002;77:1071-3.

2 Deffarges JV, Haddad B, Musset R, et al. Utero-vaginal anastomosis in women with uterine cervix atresia: long-term follow-up and reproductive performance. A study of 18 cases. Hum Reprod 2001;16:1722-5

3 Hampton $\mathrm{HL}$. Role of the gynecologic surgeon in the management of urogenital anomalies in adolescents. Curr Opin Obstet Gynecol 1990;2:812-8.

4 Gasim T, Al Jama FE. Massive Hematometra due to congenital cervicovaginal agenesis in an adolescent girl treated by hysterectomy: a case report. Case Rep Obstet Gynecol 2013;2013:1-3.

5 Mishra V, Saini SR, Nanda S, et al. Uterine conserving surgery in a case of cervicovaginal agenesis with unicornuate uterus. J Hum Reprod Sci 2016;9:267.

6 Jeon G-H, Kim SH, Chae HD, et al. Simple uterovaginal anastomosis for cervicovaginal atresia diagnosed by magnetic resonance imaging: a report of two cases. J Obstet Gynaecol Res 2016;42:738-42.

7 Bagga R, Muthyala T, Saha PK, et al. Functioning left uterine horn with cervico-vaginal atresia and ovarian maldescent - an unclassified Müllerian anomaly treated with hornvaginal anastomosis. J Obstet Gynaecol 2018;38:1176-8.

8 Kriplani A, Kachhawa G, Awasthi D, et al. Laparoscopic-assisted uterovaginal anastomosis in congenital atresia of uterine cervix: follow-up study. J Minim Invasive Gynecol 2012;19:477-84.

9 Azinar AD, Annas JY, Primariawan RY, et al. Treatment of cervical agenesis with minimally invasive therapy: case report. Gynecol Minim Invasive Ther 2017;6:202-4.

Copyright 2021 BMJ Publishing Group. All rights reserved. For permission to reuse any of this content visit https://www.bmj.com/company/products-services/rights-and-licensing/permissions/

BMJ Case Report Fellows may re-use this article for personal use and teaching without any further permission.

Become a Fellow of BMJ Case Reports today and you can:

- Submit as many cases as you like

- Enjoy fast sympathetic peer review and rapid publication of accepted articles

- Access all the published articles

- Re-use any of the published material for personal use and teaching without further permission

Customer Service

If you have any further queries about your subscription, please contact our customer services team on +44 (0) 2071111105 or via email at support@bmj.com.

Visit casereports.bmj.com for more articles like this and to become a Fellow 